\title{
Protein PRRC1
}

National Cancer Institute

\section{Source}

National Cancer Institute. Protein PRRC1. NCI Thesaurus. Code C126637.

Protein PRRC1 (445 aa, $\sim 47 \mathrm{kDa}$ ) is encoded by the human PRRC1 gene. The function of this protein is unknown. 